\title{
Humanize your business. The role of personal reputation in the sharing economy
}

\author{
Aurelio G. Mauri ${ }^{\mathrm{a}}$, Roberta Minazzi ${ }^{\mathrm{b}, 1}$, Marta Nieto García ${ }^{\mathrm{c}}$, Giampaolo Viglia ${ }^{\mathrm{d}}$
}

a IULM University, Department of Business, Law, Economics and Consumer Behaviour, via Carlo Bo 1, 20143 Milano, Italy, aurelio.mauri@iulm.it.

${ }^{\mathrm{b}}$ University of Insubria, Department of Law, Economics and Cultures, via Sant'Abbondio 12, 22100 Como, Italy, roberta.minazzi@ uninsubria.it.

${ }^{c}$ University of Portsmouth, Department of Marketing and Sales, Richmond Building Portland Street PO13DE Portsmouth, UK, marta.garcia@ port.ac.uk.

${ }^{\mathrm{d}}$ University of Portsmouth, Department of Marketing and Sales, Richmond Building Portland Street PO13DE Portsmouth, UK, giampaolo.viglia@ port.ac.uk.

\footnotetext{
${ }^{1}$ roberta.minazzi@ uninsubria.it, corresponding author.
} 


\title{
Humanize your business. The role of personal reputation in the sharing economy
}

\begin{abstract}
Drawing on the services marketing and sharing economy literature, the study identifies the leading reputational attributes that boost popularity in sharing economy platforms. As popularity stands as a purchase decisionmaking tool, the purpose of this paper is to jointly examine the influence of personal reputation and product description. A sample of Airbnb listings was collected in November 2016 in Italy and UK ( $n=502)$. The database consists of popularity variables along with personal reputational attributes and the description of the product being offered. The findings of the study, based on the Shapley Value Regression, suggest that personal reputation is of paramount importance, explaining alone almost $40 \%$ of popularity variation. The paper concludes with theoretical implications on self-branding and, given the importance weights of the different attributes in popularity building, practical implications for sellers operating in sharing economy platforms.
\end{abstract}

Keywords: Sharing economy, Airbnb, personal reputation, decision-making, popularity

\section{Introduction}

In recent years, the so-called sharing economy has become a common practice in many fields. Retailing, hospitality, transportation, and computing are just some examples of sectors affected by this practice. The proliferation of these consumption models based on a shared access to goods and services is especially encouraged by the rapid development of technology (Belk, 2010; Botsman and Rogers, 2010; Albinsson and Yasanthi Perera, 2012). In particular, the spread of platforms and social media applications and the growing user-connectivity facilitate the creation of online peer communities. People can share information, experiences and increasingly also goods and services for a certain period of time by paying a fee or through social market norms (Bardhi and Eckhardt, 2012). Thanks to technology improvements, a consumption model that in the past was perceived as inferior (Ronald, 2008) in the last decade has become a noteworthy phenomenon due to economic, social and cultural changes (Bauman, 2013; Bardhi, Eckhardt, and Arnould 2012; Zervas, Proserpio and Byers, 2015). These consumption trends have led to the development of new business models: Airbnb, Zipcar and Uber, just to name a few. These companies are generally considered examples of "disrupting innovation" (Christensen, 1997; Schneider 2017), because they make use of innovative technologies to create platforms where people can easily share products and experiences.

One of the sectors affected by sharing economy is certainly accommodation. The spread of this new model of consumption has tremendously expanded the hospitality sector beyond any previous boundary (Guttentag, 2015; Zervas, Proserpio and Byers, 2015). The most well-known example of sharing economy operator in the hospitality sector is Airbnb, a marketplace where people can rent rooms or entire flats mainly for short periods. The main operating principle is the creation of a community of hosts and guests who share services, 
information, and experiences (Yannopoulou, Moufahim and Bian, 2013). Although one strong reason to choose Airbnb is generally that it costs less than traditional accommodation services (Guttentag, 2015; Priporas et al., 2017), cultural and social factors have increasingly gained importance (Ikkala and Lampinen 2015; Lee et al., 2015; Möhlmann, 2015; Zhu et al., 2017). The act of sharing is generally "a step toward creating social connection and community" (Albinsson and Yasanthi Perera, 2012, p. 311), in which positive social ties take place (John, 2013).

Previous research on sharing economy (Cheng, 2016) has focused on five research streams, lifestyle and social movement, consumption practice, sharing paradigm, trust, and innovation. Additional socio-economic effects of sharing economy have been identified with regards to new trends in consumer behaviour (Tussyadiah and Pesonen, 2015; Sigala, 2015; Pappas, 2017), behaviours of operators (Zervas, Proserpio and Byers, 2015) and value co-creation (Camilleri and Neuhofer, 2017; Johnson and Neuhofer, 2017). Furthermore, the spread of these models has created concern about legal issues (Guttentag, 2015; Williams and Horodnic, 2017).

Few studies have examined the popularity determinants in this sharing economy context. Liang, Schuckert, Law and Chen (2017) showed that consumers are willing to spend more on popular accommodations, suggesting that popularity is a helpful cue to better inform judgment and consumers' decision making. While informative description and reputation have been shown to boost brand popularity in traditional markets (De Vries, Gensler and Leeflang, 2012; Viglia, Furlan and Ladron-de-Guevara, 2014) the specific relevance of these variables in the sharing economy industry is scant.

The purpose of the paper is to examine the role and influence of personal reputation and product description in popularity building within the sharing economy context. This study is part of the stream of research related to consumption practice, as identified by Cheng (2016). The theoretical angle is interdisciplinary, drawing from sociological and economic perspectives. The paper investigates the identified relationships through Shapley Value Regression with a sample of 502 Airbnb listings. The choice of focusing the analysis on a single case (Airbnb) is motivated by the central role played by this platform in transforming the tourism accommodation sector (Oskam and Boswijk, 2016; Guttentag and Smith, 2017).

\section{Conceptual framework and hypotheses development}

Sharing economy has been heralded as a strategic innovation, with an increasing number of articles and books on the topic (ISI Web of Science, 2017). This phenomenon is analysed in various research fields with different conceptualizations (Belk, 2014). Some of these include collaborative consumption (Botsman and Rogers, 2010), co-production (Humphreys and Grayson, 2008), co-creation (Prahalad and Ramaswamy, 2004), prosumption (Toffler and Alvin, 1980), access-based consumption (Bardhi and Eckhardt, 2012), consumer participation (Fitzsimmons, 1985), commons-based peer production (Benkler and Nissenbaum, 2006) and social sharing or shareable goods (Benkler, 2004). Although there is no consensus on a unique definition of sharing economy, scholars and practitioners agree it is a disruptive innovation in the current social economic system (PwC, 2015; Schor and Fitzmaurice, 2015).

Theoretically, sharing economy has its roots in the idea of gift giving (Belk, 2007), with past research investigating the psychological motivations for sharing (Bardhi and Eckhardt, 2012). In recent times, these boundaries have been extended and now sharing is mainly based on market transactions (Kennedy, 2016; Heo, 
2016). The present study embraces the "collaborative consumption" definition of sharing economy by Belk (2014), where people coordinate for "the acquisition and distribution of a resource for a fee or other compensation" (p. 1597). This conceptualization rules out other definitions of sharing economy not based on monetary transactions. An example of these non-monetary sharing economy markets is CouchSurfing (Pera et al., 2016). Sharing economy platforms like Airbnb enable individuals to charge a fee for offering accommodation services. In this sense, hosts operate as micro-entrepreneurs (Sundararajan, 2014; Teubner, Hawlitschek and Dann, 2017). Today, there is a subtle line between private and professional providers on sharing economy platforms (Zervas, Proserpio and Byers 2015). Indeed, despite the differences between the two categories of actors (Li, Moreno and Zhang, 2015), the popularity of Airbnb attracts an increasing number of semi-professionals with multiple listings (Teubner, Hawlitschek and Dann, 2017, Ke, 2017).

From a theoretical standpoint, our analysis is based mainly on social comparison theory (Festinger, 1954), and signaling theory (Spence, 2002). Those theories explain how customers form judgments using available cues and being influenced by others' decisions. In unveiling so, we jointly measure the role of product description and we control for other possible confounding factors. The present study focuses on Airbnb listings due to both practical and academic reasons. First, recent research demonstrates that Airbnb is the most noticeable example of the sharing economy in the hospitality industry (Guttentag, 2015; Ert et al., 2016). The platform counts 3 million listings in 65,000 cities in 191 countries all over the world and it is increasingly considered by customers during the travel decision process, with 150 million guests since its foundation in 2008 (Airbnb, 2017). Second, an analysis of the sharing economy topic in the hospitality industry literature over the last three years (20152017) demonstrates the interest of scholars towards the case Airbnb. The main research themes are presented in Table 1 and primarily revolve around these areas: i) value creation practices (Camilleri and Neuhofer, 2017; Johnson and Neuhofer, 2017), ii) effects on consumers' preferences and decisions (Varma et al., 2016; Tussyadiah, 2015; Mao and Lyu, 2017; Poon and Huang, 2017; Tussyadiah and Zach, 2017), iii) impacts on the hotel sector and changing relationships between the actors (Zervas et al., 2015; Guttentag and Smith, 2017; Mody et al., 2017), iv) effects of attributes of Airbnb listings on performance (Xie and Mao, 2017) and v) pricing (Chen and Xie, 2017; Wang and Nicolau, 2017).

\subsection{Popularity}

According to social comparison theory (Festinger, 1954), popular alternatives have higher probability to be selected. Individuals usually believe that the majority is right (Denrell and Le Mens, 2012) and make decisions based on this reasoning. The trend to emulate peers in selected choices, named bandwagon effect, has been studied in the context of behavioural sciences (Salganik et al., 2008; Bass, 1969). Internet users, who are increasingly overwhelmed by information and quality uncertainty, adopt popular decisions to simplify their decision-making processes (Fu and Sim, 2011). Across different online contexts, acts of social compliance were shown to reflect in high revenues (Liu, 2006; De Vries et al, 2012). Recently, Viglia et al. (2014) has found that consumers' preference increases with the popularity of the offer.

While social comparison theory explain why individual follow peers, signaling theory (Spence, 2002) concerns the complex signaling processes that occur during a transaction between the transaction parties (in our specific case hosts and guests). This process is specifically salient when asymmetrical information is present (Connelly et al., 2011; Teubner, Hawlitschek and Dann, 2017). To reduce information asymmetry, providers can signal the 
products' quality by means of specific indicators (signals) that are generally classified in conventional, handicap or index (Spence, 2002). Operationalizing these concepts in hospitality, conventional signals regard the information provided by the host (i.e. self-descriptions), handicap signals explicate a deeper effort of the host before and during the transaction (i.e. ID disclosure, host-guest interactions), and index signals are the final results coming from peer experiences (i.e. reviews and other reputational indicators). With the development of technology and social media, these last signals are really accessible indicators (number of reviews, number of like, number of followers, etc.) (De Vries et al, 2012; Sabate et al. 2014). Online ratings become crucial since they are the result of previous peers' experiences. They can be considered a first source of popularity in that they are perceived more helpful and trustable than information coming from the company itself (Resnick and Zeckhauser, 2002; Yacouel and Fleischer, 2012; Sparks and Browning, 2011; Mauri and Minazzi, 2013; Abrahao et al. 2017). Nonetheless, in the sharing economy arena, products have generally overwhelming positive reviews (Zervas, Proserpio and Byers, 2015). In the particular case of the hospitality sector, previous studies found that more than $90 \%$ of Airbnb properties boast an average user-generated rating of either 4.5 or 5 stars (Zervas and Proserpio, 2015). This can lead travellers to look for other cues to inform their decisions (Dellarocas and Wood 2008; Bolton et al, 2013). In addition to online ratings, the number of reviews (WOM volume) can be considered a main constituent of popularity along with similar preference cues left by consumers (Chevalier and Mayzlin, 2006; Liu, 2006; Park, Lee and Han, 2007; Viglia et al., 2014). In an information overload context, popularity stands out as a cue that helps consumer decision-making and can be seen as a viral marketing form (Gunawan \& Huarng, 2015).

\subsection{Personal reputation}

Signals coming from the service provider play a crucial role in decreasing information asymmetry (Connelly et al., 2011). The increasing opportunity to share personal information directly or through other social media (i.e. Facebook, LinkedIn, Youtube, etc.) further allows reducing information asymmetries between the seller and the consumer. In sharing economy transactions, there is a higher perception of risk toward the person who provides the service with respect to the product itself (Tussyadiah, 2016b). The act of sharing a home with a stranger, what Belk (2014) defines as "sharing out", is itself risky and gives more and more importance to the seller's personal reputation as a critical factor in ensuring service quality. As a consequence, in the sharing economy markets, compared to traditional online markets, consumers pay substantial attention to personal information and ratings, as those evaluations are considered a valuable source of information and reliability affecting the whole purchasing experience (Ert, Fleischer and Magen, 2016; Lu and Kandampully, 2016). Previous studies have confirmed the importance of identity disclosure in online interaction (Liu and Park, 2015), claiming that the personal identification of the seller plays a major role in reputation building (Edelman and Luca, 2014; Germann Molz, 2013). Wang and Nicolau (2017) found that host's attributes on Airbnb are important price determinants in that guests in sharing economy perceive these features as quality signals that affect their willingness to pay a premium price. On this topic, various studies found that personal identifying information helps people in taking favourable decisions (Forman et al. 2008; Xie et al. 2011) humanizing social contact (Botsman and Rogers, 2010, Tussyadiah and Pesonen 2015). In particular, photos can be used to verify the identity of the seller to increase the sense of personal contact (Guttentag, 2015; Ert et al. 2016). Another important component of personal information is the sellers' responsive behaviour (Tussyadiah, 2016b). Finally, the ability of the communicator to engage the receiver of the message through storytelling has been 
operationalized in the hospitality industry and resulted to be a cornerstone of personal reputation (Pera et al., 2016). Considering the importance of personal information of the seller in sharing economy, a specific branch of research investigates personal branding, i.e. self-marketing strategies that people can use to present themselves (Labrecque, Markos and Milne, 2011; Kim and Tussyadiah, 2013; Liu and Mattila, 2017).

In the light of the previous literature, we expect a strong relation between personal reputation and popularity. More formally:

H1: Personal reputation positively affects popularity in the sharing economy

\subsection{Product description}

Product description plays a main role in the context of services, where quality is difficult to assess prior to consumption. Informative cues are therefore helpful to reduce the level of uncertainty regarding the product (Resnick and Zeckhauser, 2002). When consumers view a product listed on a website, they may not be able to judge accurately its quality (Fung and Lee, 1999). Consumers' perceptions of the diagnosticity of product websites influence their attitudes toward shopping at that website (Jiang and Benbasat, 2007). In this line, any information a consumer finds about a good or service helps their decision-making processes by reducing information asymmetries (Pavlou and Dimoka, 2006; Helm and Mark, 2007). In particular, the amount of information consumers need to process and the time spent in processing it rises when there is more uncertainty (Huang, Lurie and Mitra, 2009). Therefore, companies provide increasing amounts of product information to persuade digital consumers (Lee and Lee 2004).

Previous research in the tourism and hospitality industry domain has examined the level of information detail provided by hotel websites, and found that a more informative orientation pays off in terms of consumer preference (Escobar-Rodríguez and Carvajal-Trujillo, 2013). Product description should also be powerful in terms of popularity building in the sharing economy realm, especially when the description goes beyond the basic information and gives more insights about the tourist destination using visual content too. Recent studies confirm the powerful role of visual content as predictor of online popularity (Sabate et al. 2014; Trefzger, Baccarella and Voigt, 2015, Wang et al. 2016). Therefore, detailed information about the destination and clear pictures may give additional value to consumers. All this is expected to enhance popularity. Formally:

H2: Product description positively affects popularity in sharing economy. 
Table 1. Airbnb studies (2015-2017)

\begin{tabular}{|c|c|c|}
\hline Research themes & Academic papers & Title/Main results \\
\hline \multirow{8}{*}{$\begin{array}{l}\text { Value creation } \\
\text { practices }\end{array}$} & $\begin{array}{c}\text { Camilleri and } \\
\text { Neuhofer, } 2017\end{array}$ & $\begin{array}{l}\text { Value co-creation and co-destruction in the Airbnb sharing economy. Six distinct themes of guest-host social practices and their sub-categories are } \\
\text { proposed, resulting in a spectrum of dimensions of value formation. }\end{array}$ \\
\hline & $\begin{array}{l}\text { Johnson and Neuhofer, } \\
2017\end{array}$ & $\begin{array}{l}\text { Airbnb-An exploration of value co-creation experiences in Jamaica. A theoretical framework s proposed about host-guest value co-creation practices } \\
\text { embedded in the destination's authentic culture. }\end{array}$ \\
\hline & Varma et al., 2016 & $\begin{array}{l}\text { Airbnb: Exciting innovation or passing fad? There are significant differences between the type and motivation of customers that book Airbnb compared } \\
\text { to those that book traditional hotels. The major players in the hospitality industry do not indicate Airbnb as a significant disruptor and/or competitor. }\end{array}$ \\
\hline & $\begin{array}{l}\text { Brochado, Troilo and } \\
\quad \text { Shah, } 2017\end{array}$ & $\begin{array}{l}\text { Airbnb customer experience: Evidence of convergence across three. The study examines the convergence existing across nations and cultures in } \\
\text { customer experiences in Airbnb. }\end{array}$ \\
\hline & Liu and Mattila, 2017 & $\begin{array}{l}\text { Airbnb: Online targeted advertising, sense of power, and consumer decisions. Powerless individuals respond more favorably to the belongingness } \\
\text { appeal, whereas powerful individuals react more positively to the uniqueness appeal. These effects are explained by self-brand connection. }\end{array}$ \\
\hline & Mao and Lyu, 2017 & $\begin{array}{l}\text { Why travelers use Airbnb again? An integrative approach to understanding travelers' repurchase intention. Attitude and subject norms are significant } \\
\text { determinants of repurchase intention on Airbnb. Perceived value and risk have a direct significant impact on attitude and in turn, indirectly influence } \\
\text { repurchase intention. }\end{array}$ \\
\hline & Poon and Huang, 2017 & $\begin{array}{l}\text { Past experience, traveler personality, and tripographics on intention to use AirBnB. Airbnb users and non-users present similarities in their } \\
\text { demographics and perceived importance of accommodation attributes while they differ in the perception of Airbnb and its evaluation compared to hotels. }\end{array}$ \\
\hline & $\begin{array}{l}\text { Tussyadiah and Zach, } \\
\qquad 2017\end{array}$ & $\begin{array}{l}\text { Identifying salient attributes of peer-to-peer accommodation experience. Attributes frequently mentioned in guest reviews are associated with location, } \\
\text { host, and property. } \mathrm{P} 2 \mathrm{P} \text { accommodation appeal to consumers who are driven by experiential and social motivations. }\end{array}$ \\
\hline \multirow{4}{*}{$\begin{array}{l}\text { Impacts on the } \\
\text { hotel sector and } \\
\text { changing } \\
\text { relationships } \\
\text { between the actors }\end{array}$} & $\begin{array}{l}\text { Zervas, Proserpio and } \\
\text { Byers, } 2015\end{array}$ & $\begin{array}{l}\text { The impact of the sharing economy on the hotel industry: evidence from Airbnb's entry into the Texas market. Peer -to-peer platforms influence some } \\
\text { specific types of hotels, i.e. Mid-range hotels whose target is not business travelers. }\end{array}$ \\
\hline & $\begin{array}{l}\text { Lu and Kandampully, } \\
2016\end{array}$ & $\begin{array}{l}\text { What drives customers to use access-based sharing options in the hospitality industry? The study proposes a conceptual model to illustrate the } \\
\text { relationship between customers, sharing firms, service providers and their relationship with online platforms and social media. }\end{array}$ \\
\hline & $\begin{array}{l}\text { Guttentag and Smith, } \\
2017\end{array}$ & $\begin{array}{l}\text { Assessing Airbnb as a disruptive innovation relative to hotels: Substitution and comparative performance expectations. Many Airbnb guests use Airbnb } \\
\text { as a substitute for hotels, especially mid-range hotels. }\end{array}$ \\
\hline & $\begin{array}{l}\text { Mody, Suess, and } \\
\text { Lehto, } 2017\end{array}$ & $\begin{array}{l}\text { The accommodation experiencescape: a comparative assessment of hotels and Airbnb. Airbnb appears to outperform the hotel industry in the provision } \\
\text { of several experience dimensions (Pine and Gilmore's experience economy construct plus other dimensions serendipity, localness, communitas, and } \\
\text { personalization). }\end{array}$ \\
\hline \multirow{3}{*}{$\begin{array}{l}\text { Effects of attributes } \\
\text { of Airbnb listings } \\
\text { on performance } \\
\text { and pricing }\end{array}$} & Chen and Xie, 2017 & $\begin{array}{l}\text { Consumer valuation of Airbnb listings: a hedonic pricing approach. Functional characteristics of Airbnb listings are significantly associated to the price } \\
\text { of the listings. Five behavioral attributes of hosts are statistically significant. }\end{array}$ \\
\hline & Xie and Mao, 2017 & $\begin{array}{l}\text { The impacts of quality and quantity attributes of Airbnb hosts on listing performance. Host quality attributes significantly influence listings performance } \\
\text { through cue-based trust. A trade-off' between host quality and the quantity of their listings emerges by the study. }\end{array}$ \\
\hline & $\begin{array}{l}\text { Wang and Nicolau, } \\
2017\end{array}$ & $\begin{array}{l}\text { Price determinants of sharing economy based accommodation rental: A study of listings from } 33 \text { cities on Airbnb.com } \\
\text { The study identifies the factors determining the price of sharing economy-based accommodation. Hosts with superhost status, more listings, and verified } \\
\text { identities usually are able to charge higher prices. }\end{array}$ \\
\hline
\end{tabular}




\subsection{Personal reputation vs product description}

While both personal reputation and product description should play an important role in driving popularity, previous research has overlooked at which of these two sources is more important.

Product presentation is a seller-generated information cue that originates from the seller itself (Wang et al., 2016) while seller reputation contains also user-generated information cue that derives from customers and it is based on their own purchasing and using experience. As mentioned previously, user-generated content cues are generally perceived more helpful and credible than information coming from the seller (Resnick and Zeckhauser, 2002; Yacouel and Fleischer, 2012; Sparks and Browning, 2011). In the sharing economy case, the act of sharing a home with a stranger determines a high level of human interaction and a high level of risk. In this context, the role of personal reputation should represent the key factor with respect to product description that drives the decisions of customers evaluating alternative offers. Given the importance of human interactions in sharing economy, we assume that personal reputation of the seller plays outweighs the role of product description in influencing popularity. More formally:

H3: Given the salience of human interactions in sharing economy, personal reputation outweighs product description in popularity building.

\section{Research methodology}

Shapley Value Regression measures the impact of product description factors and personal reputation factors on popularity. This methodology is suitable for this study since it can handle multicollinearity and it gives the opportunity to focus on the contribution of a-priori defined groups rather than single variables (Huettner and Sunder, 2012). The technique has been used in previous studies to estimate the contribution of each variable, or groups of variables to a response variable (Viglia and Abrate, 2017; de la Peña et al., 2016).

\subsection{Shapley Value Regression}

This study aims to understand the relative importance of product description and personal reputation factors, rather than estimating specific coefficients. Given this, the Shapley Value Regression (SVR) constitutes an appropriate technique since it estimates the contribution of predictors to a response variable by aggregating predictors in groups (Shapley 1953; Lipovetsky and Conklin, 2001). This typology of regression considers all possible combinations of predictors and estimates the goodness-of-fit improvement by averaging over these combinations.

Formally, given a regression model with $\mathrm{K}$ regressors, $\left(\mathrm{x}_{1}, \mathrm{x}_{2}, \ldots, \mathrm{x}_{\mathrm{K}}\right)$, all possible sub-models (considering all $\mathrm{K}$ ! permutations of regressors) are estimated in order to compute the contribution of each variable:

$$
R_{j}^{2}=\frac{1}{K !} \sum_{\theta} R^{2}\left(f\left(x_{j}^{\theta}, x_{j}\right)\right)-R^{2}\left(f\left(x_{j}^{\theta}\right)\right)
$$

where $\theta$ defines any of the $\mathrm{K}$ ! variable orderings. The marginal contribution to $\mathrm{R}$-squared is given by the Rsquared of the model that includes $x_{j}$ and all regressors preceding $x_{j}$ in that particular order $\left(x_{j}^{\theta}\right)$ minus the $R$ squared of the model that does not include $\mathrm{x}_{\mathrm{j}}$. 


\section{Data}

Data for this study were collected on the Airbnb platform. The sample was collected in November 2016 and it comprises of 502 listings in two cities, Milan $(n=249)$ and London $(n=253)$. These cities were chosen as they are two of the major business cities in Europe (Pwc, 2016), which allows isolating seasonality issues in pure tourism cities. Within each city, we collected listings in a space of $1 \mathrm{~km}$ squared, to avoid spatial location effects. The database contains three groups of variables. Popularity variables comprise "Rating", "Number of reviews of the listing" and "Times saved to wish lists". On average, as can be seen from Table 2, an Airbnb listing has a very high rating, 3.92 out of 5, has received 49 reviews and has been saved 425 times in wish lists. Personal reputation variables include "Superhost", "Number of host's reviews", "Storytelling" (in line with Pera et al. 2016 classification), "Personal photos", "Verified", "Response rate" and "Response time". The "Superhost" attribute, a distinctive institutional mechanism to signal highly reputed owners, represents the $20 \%$ of owners. Most of the requests were answered within an hour (77.1\%). Finally, the group of product description comprises the variables "Space", "Guest access", "Interaction with guests", "Neighbourhood", "Getting around", “Other things to note", "Number of pictures" and "Instant booking". Control variables include "Price", "City", "Registered from" and "Agency". The average host joined Airbnb 2 years and 10 months before the data collection. Most of the hosts $(91.4 \%)$ were non-businesses and the rest of them $(n=43)$ were announced as property managers or rental firms.

Table 2. Descriptive statistics

\begin{tabular}{|c|c|c|c|c|c|c|c|}
\hline Type & Variable & \multicolumn{2}{|c|}{ Variable description } & Mean & Std. Dev. & Min & Max \\
\hline \multirow{3}{*}{ Popularity $(D V)$} & $P_{R A T}$ & \multicolumn{2}{|c|}{ Rating } & 3.92 & 1.72 & 1 & 5 \\
\hline & $P_{R E V}$ & \multicolumn{2}{|c|}{ Number of reviews } & 48.68 & 59.02 & 0 & 309 \\
\hline & $P_{W I S H}$ & \multicolumn{2}{|c|}{ Times saved to wishlists } & 425.18 & 575.63 & 0 & 5,370 \\
\hline \multirow{12}{*}{$\begin{array}{l}\text { Personal reputation } \\
(P R)\end{array}$} & $P R_{S H O S T}$ & \multicolumn{2}{|c|}{ Superhost } & $19.52 \%$ & & & \\
\hline & $P R_{R E V}$ & \multicolumn{2}{|c|}{ Number of host's reviews } & 195.43 & 437.14 & 0 & 5,772 \\
\hline & $P R_{A C C}$ & \multicolumn{2}{|c|}{ Connected accounts } & 0.27 & 0.51 & 0 & 3 \\
\hline & $P R_{R E F}$ & \multicolumn{2}{|c|}{ Number of references } & 0.36 & 1.27 & 0 & 12 \\
\hline & $P R_{S T O R Y}$ & \multicolumn{2}{|c|}{ Storytelling } & $51.20 \%$ & & & \\
\hline & PRРното & \multicolumn{2}{|l|}{ Personal photos } & $37.45 \%$ & & & \\
\hline & $P R_{V E R}$ & \multicolumn{2}{|l|}{ Verified } & $65.34 \%$ & & & \\
\hline & $P R_{R R}$ & \multicolumn{2}{|l|}{ Response rate } & 94.28 & 20.18 & 0 & 100 \\
\hline & \multirow[t]{4}{*}{$P R_{R T}$} & \multirow[t]{4}{*}{ Response time } & n.a. & $3.78 \%$ & & & \\
\hline & & & Within an hour & $77.09 \%$ & & & \\
\hline & & & Few hours & $16.53 \%$ & & & \\
\hline & & & One day or more & $2.59 \%$ & & & \\
\hline \multirow{7}{*}{$\begin{array}{l}\text { Product description } \\
(P D)\end{array}$} & $P D_{S P A C E}$ & \multicolumn{2}{|l|}{ Space } & $75.50 \%$ & & & \\
\hline & $P D_{A C C}$ & \multicolumn{2}{|l|}{ Guest access } & $63.94 \%$ & & & \\
\hline & $P D_{I N T}$ & \multicolumn{2}{|l|}{ Interaction } & $53.19 \%$ & & & \\
\hline & $P D_{N E I G}$ & \multicolumn{2}{|l|}{ Neighbourhood } & $59.36 \%$ & & & \\
\hline & $P D_{G E T}$ & \multicolumn{2}{|l|}{ Getting around } & $71.31 \%$ & & & \\
\hline & PDOTHER & \multicolumn{2}{|c|}{ Other things to note } & $45.27 \%$ & & & \\
\hline & $P D_{S A F E T Y}$ & \multicolumn{2}{|c|}{ Safety features } & $68.53 \%$ & & & \\
\hline
\end{tabular}




\begin{tabular}{lllllll} 
& $P D$ PICT & Number of pictures & 18.24 & 10.88 & 1 & 69 \\
& $P D_{I N S T}$ & Instant booking & $51.39 \%$ & & & \\
\hline \multirow{3}{*}{ Control variables } & $C_{\text {PRICE }}$ & Price per night & 112.62 & 85.10 & 14 & 800 \\
& $C_{\text {LON }}$ & London & $50.4 \%$ & & & \\
& $C_{M I L}$ & Milan & $49.6 \%$ & & \\
& $C_{S I N C E}$ & Registered from (years) & 2.86 & 1.57 & 0.17 & 7 \\
& $C_{B U S S}$ & Agency & $8.56 \%$ & & & \\
\hline
\end{tabular}

In the case of dummy variables (taking value 1 if the service or characteristic is present and value 0 if it is not), the average value is presented, which corresponds to the percentage of listings in the sample holding that specific characteristic.

The three variables related to popularity ("Rating", "Number of reviews" and "Times saved to wish lists") were reduced through a principal component analysis (PCA) to determine a popularity index. The factor reduction revealed that a single component solution explains alone $63.54 \%$ of observed variance. The Kaiser-Mayer-Olkin (KMO) sample of adequacy was over $0.5(p<0.01)$, confirming the reliability of the construct. Overall, the popularity index results from the aggregation of the three variables ("Rating", "Number of reviews" and "Times saved to wish lists"). The degree to which each of these variables contributes to the popularity index is 0.379 for "Rating", 0.790 for "Number of reviews" and 0.738 for "Times saved to wish lists".

\section{Results}

To unpack the role of personal reputation and product description, the proposed technique (SVR) requires the estimation of a model where popularity depends on these two group of variables.

Four variables ("Price", "City", "Registered from" and "Agency") were introduced in the model to control for unobserved heterogeneity.

Table 3 presents the results of the SVR. The SVR decomposition of R-squared values, informs on the relative weight of the single variables to the variation of the popularity index. The estimation presents a reasonably good fit $(\mathrm{R}$-squared $=0.253)$. The results reveal that personal reputation is more relevant than product description in terms of popularity building (39.04\% vs. $36.59 \%)$.

Table 3. Popularity determinants (Shapley Value Regression)

\begin{tabular}{lcc}
\hline Variables & Contribution & Direction of the impact \\
\hline Personal reputation & $39.04 \%$ & + \\
\hline Superhost & $7.05 \%$ & + \\
Number of host's reviews & $5.32 \%$ & - \\
Connected accounts & $5.91 \%$ & + \\
Number of references & $5.32 \%$ & + \\
Storytelling & $8.15 \%$ & + \\
Personal photos & $1.73 \%$ & + \\
Verified & $1.61 \%$ & + \\
Response rate & $2.50 \%$ & - \\
Response time & $1.45 \%$ & + \\
\hline Product description & $36.59 \%$ & - \\
\hline Space & $5.29 \%$ & - \\
Guest access & $2.01 \%$ & + \\
Interaction & $3.86 \%$ & + \\
Neighbourhood & $1.59 \%$ & + \\
Getting around & $1.43 \%$ & - \\
Other things to note & $6.39 \%$ & + \\
Safety features & $6.67 \%$ & + \\
Number of pictures & $7.38 \%$ & \\
Instant booking & $1.97 \%$ & \\
\hline
\end{tabular}




\begin{tabular}{lcc}
\hline Control variables & $24.37 \%$ & - \\
\hline Price per night & $5.28 \%$ & + \\
City (0:Milan; 1:London) & $4.81 \%$ & - \\
Registered from (years) & $12.39 \%$ & - \\
Agency & $1.88 \%$ & $100.00 \%$ \\
\hline Total & \\
\hline Dependent variable is Popularity index. R-squared $=0,2531$. & \\
The R-squared is decomposed according to its determinants, by means of Shapley-Owen technique. Thus, each value represents the relative \\
contribution to $R$-squared of each group of factors.
\end{tabular}

The group of variables related to personal reputation is the major player toward popularity, with a $39.04 \%$ relative weight, which supports H1. In particular, "Storytelling" stands out for being the variable with the highest contribution to popularity $(8.15 \%)$. This result is in line with previous studies in the sharing realm, which show the role of storytelling on reputation building (Pera et al., 2016). The "Superhost" attribute has also a great influence in boosting popularity (7.05\%), consistently with Liu and Mattila (2017). Surprisingly, "Connected accounts" have a significant negative impact on popularity (5.32\%). This negative contribution supports the idea that personal reputation variables, if not handled in a proper way, could undermine popularity. The second hypothesis of the study, which claims that product description affects popularity, is also supported. The group of variables linked to product description influences popularity with a $36.59 \%$ impact. Within this group, the highest contribution corresponds to "Number of pictures" (7.38\%). This result is in parallel with previous research on the hospitality industry that remarks the relevance of visual content (Sabate et al. 2014; Trefzger, Baccarella and Voigt, 2015). "Safety features", with an impact of $6.67 \%$, contribute to popularity in a negative way. A remarkable contribution (6.39\%) comes from "Other things to note", a section offering special detailed information about the listing.

Finally, in the group of control variables, it is also worth noting the contribution of "Price" (5.28\%), with a negative influence on popularity. A possible explanation for this finding is that listings with higher prices per night are less popular than those with lower prices. Finally, "City" accounts for less than 5\% of the variation of popularity meaning that, regardless of the city, listings seem to have comparable levels of popularity.

To sum up, these results state that personal reputation is crucial in building popularity, explaining alone almost $40 \%$ of the popularity variation. Interestingly, product description has a slightly more limited overall impact on popularity. It is also relevant to note that product descriptions, compared to personal reputation, present on more instances a negative impact on popularity (three versus two cases). It follows that providing more personal information seems more effective than providing more information on the product being advertised.

Figure 1 summarizes the empirical findings graphically, showing how personal reputation comes first in explaining popularity. 


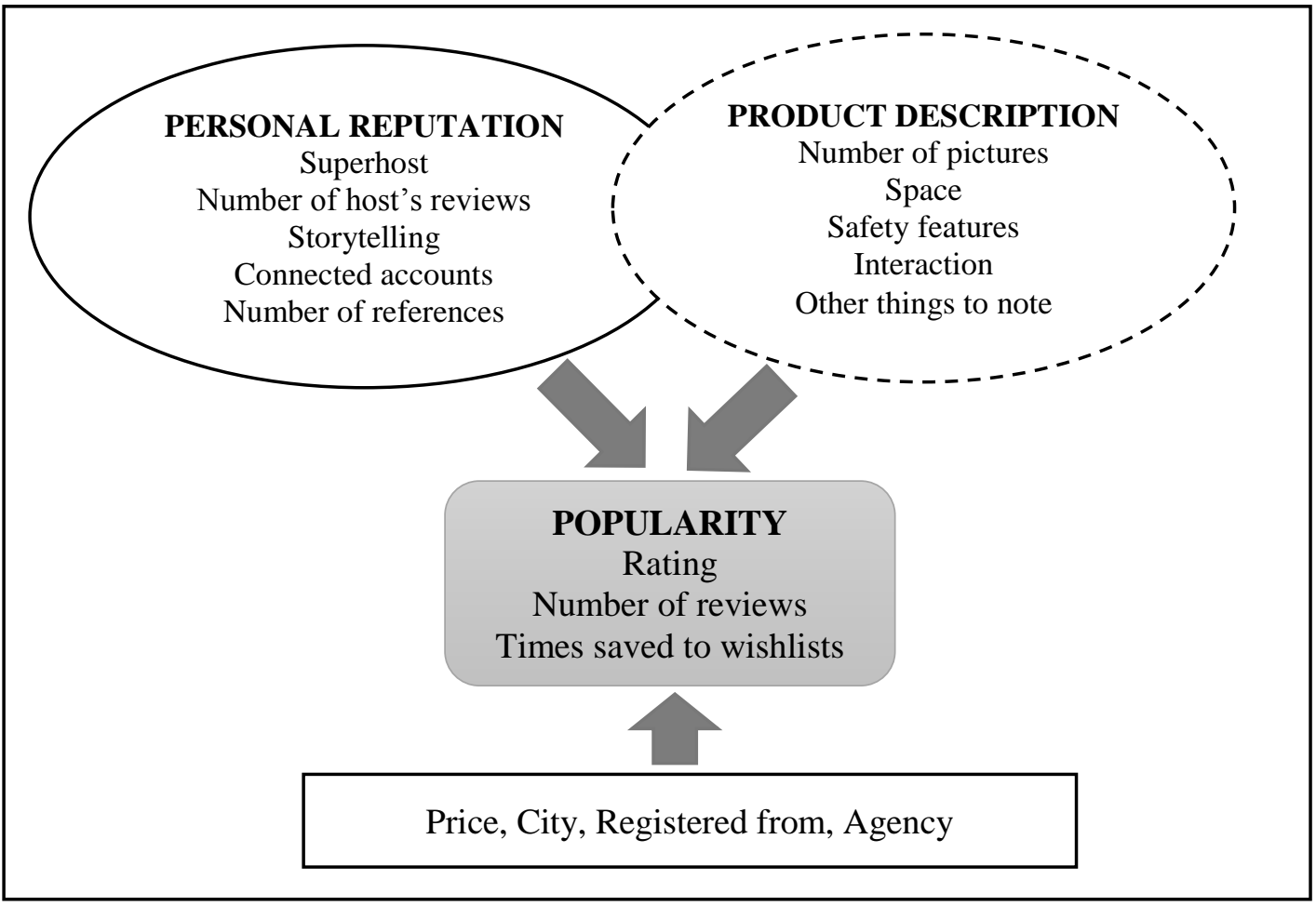

\section{Discussion and conclusion}

Information technology facilitates peer-to-peer transactions and empowers people to market their own products in digital settings. The so-called sharing economy, despite being considered a successful disruptive innovation, is fuelled with uncertainty. Consumers operating in these markets take purchase decisions and make payment transactions with complete strangers.

This contribution starts from the assumption, already validated in previous literature (Liu, 2006; De Vries et al, 2012; Viglia et al. 2014), that popularity helps to increase consumers' preference and reduce the perceived uncertainty of the transaction, maximizing sellers' returns. The goal of this research is unclosing popularity determinants. Specifically, we claim that personal reputation is the most relevant determinant of popularity. To rule out potential alternative determinants, we jointly measure the role of product description and we control for other possible third factors.

The empirical case is based on Airbnb, a sharing economy platform considered a disruptive innovation in the accommodation sector (Guttentag, 2015; Guttentag and Smith, 2017). Airbnb receives the attention of hospitality scholars in light of the strong impact of this new sharing business model on the hotel sector (Zervas et al. 2015; Lu and Kandampully, 2016; Guttentag and Smith, 2017). Methodologically, a Shapley Value Regression analysis estimates the contribution of product description and personal reputation to popularity. The findings suggest that personal reputation, in its multi-faced operationalizations, is the core constituent of popularity, accounting for almost $40 \%$ of its variation. In particular, the presence of storytelling narratives in profiles increases by $8 \%$ the popularity of the listings, in line with previous research by Pera et al. (2016). It follows that the ability of sellers to use storytelling in their profiles can significantly boost the popularity of their offer. As a second best, product description plays a relevant part in consumer decision-making processes, 
helping to foster popularity. This finding is not surprising, as the presence of detailed product description and of visual content was already shown as relevant in reducing uncertainties about information quality (Helm and Mark, 2007; Huang, Lurie and Mitra, 2009) and information asymmetries (Pavlou and Dimoka, 2006), especially if details go beyond basic information (Park and Kim, 2003). Visual content plays a major role in product descriptions, consistently with previous studies (Sabate et al. 2014; Trefzger, Baccarella and Voigt, 2015).

The results of this study give valuable recommendations to people who want to offer a product on sharing platforms. As traditional companies invest part of their budget to enhance their brand name, in sharing economy environments single individuals have to enhance their personal reputation to boost their popularity. From the managerial standpoint, we are assisting at a new form of micro-entrepreneurship where sellers in time of crisis decide to market their products (Soriano and Huarng, 2013; Peris-Ortiz et al., 2014). In this context, we show that sellers should develop specific personal branding strategies in order to increase their popularity. Microentrepreneurs should acknowledge that customers are looking also for human experiences. In this sense, disclosure efforts to reduce uncertainty and make a close relationship with the customer, already in the online landscape, will benefit popularity levels.

Given the result of the present study, meaningful implications can be drawn also for sharing platforms managers. First, they can help sellers to understand which additional features can be embedded in their profiles to reduce the uncertainty of the transaction and information asymmetries. On this note, it particularly stands out the role of storytelling to increase the human interactions with guests prior to the face-to-face experience. Second, sharing platform managers can enrich their websites by giving more opportunities for sellers to include multimedia content. For instance, Airbnb allows uploading photos but not videos of the proposed product.

From a theoretical standpoint, this paper enriches and supports previous research on the relevance of identity disclosure in online interactions (Xie et al. 2011; Edelman and Luca, 2014). As observed by Abrahao and al. (2017), reputation plays a critical role in nurturing trustworthiness between parties. More generally, social interactions and personal identifying information are important factors that motivate sharing transactions (Tussyadiah, 2016).

The present paper is not without limitations. First, despite Airbnb is the most prominent sharing platform for lodging, it is not the only one. Future research could focus on other operators such as HomeAway suggesting comparisons among operators in the sharing economy or with more traditional hospitality actors (hotels, residences, etc.). Second, this study is exploratory and considers just two business cities (Milan and London) and a specific domain, i.e. the accommodation sector. Third, the analysis, looking at the mere presence of peripheral cues elements (Cheung et al., 2009; Mudambi and Schuff, 2010), do not examine in depth the semantics of profiles.

Future research can go beyond these limitations. A first step can be an analysis involving different cities and destinations, in order to examine our hypotheses across different geographical and cultural contexts. A second research path could examine more in depth hosts' profile both considering languages used and text content (through semantic analysis) on one side and images/photos of the hosts' profile on the other. Finally, to strengthen the validity of the findings across sectors, it would be interesting to investigate diverse sectors of the sharing economy realm too. 


\section{References}

Albinsson, P. A., \& Yasanthi Perera, B. (2012). Alternative marketplaces in the 21st century: Building community through sharing events. Journal of Consumer Behaviour, 11(4), 303-315.

Abrahao, B., Parigi, P., Gupta, A., \& Cook, K. S. (2017). Reputation offsets trust judgments based on social biases among Airbnb users. Proceedings of the National Academy of Sciences PNAS, 114 (37).

Airbnb (2017). About us. (Accessed November, 16, 2017) [Retrieved from: https://www.airbnb.ca/about/aboutus]

Bardhi, F., \& Eckhardt, G. M. (2012). Access-based consumption: The case of car sharing. Journal of Consumer

Research, 39(4), 881-898.

Bardhi, F., Eckhardt, G. M., \& Arnould, E. J. (2012). Liquid relationship to possessions. Journal of Consumer Research, 39(3), 510-529.

Bass, F.M. (1969). A new product growth model for consumer durables. Management Science, 15(5), $215-227$.

Bauman, Z. (2013). Liquid love: On the frailty of human bonds. John Wiley \& Sons.

Belk, R. (2007). Why not share rather than own? The Annals of the American Academy of Political and Social Science, 611(1), 126-140.

Belk, R. (2010). Sharing. Journal of Consumer Research, 36(5), 715-734.

Belk, R. (2014). You are what you can access: Sharing and collaborative consumption online. Journal of Business Research, 67(8), 1595-1600.

Benkler, Y. (2004). Sharing nicely: On shareable goods and the emergence of sharing as a modality of economic production. Yale Law Journal, 273-358.

Benkler, Y., \& Nissenbaum, H. (2006). Commons-based peer production and virtue. Journal of Political Philosophy, 14(4), 394-419.

Bolton, G., Greiner, B., \& Ockenfels, A. (2013). Engineering trust: reciprocity in the production of reputation information. Management Science, 59(2), 265-285.

Botsman, R., \& Rogers, R. (2010). What's mine is yours. The rise of collaborative consumption. Harper Collins Publishers, New York.

Camilleri, J., \& Neuhofer, B. (2017). Value co-creation and co-destruction in the Airbnb sharing economy. International Journal of Contemporary Hospitality Management, (forthcoming).

Chen, Y., \& Xie, K.L. (2017). Consumer valuation of Airbnb listings: a hedonic pricing approach. International Journal of Contemporary Hospitality Management, (forthcoming).

Cheng, M. (2016). Sharing economy: A review and agenda for future research. International Journal of Hospitality Management, 57, 60-70.

Cheung, M. Y., Luo, C., Sia, C. L., \& Chen, H. (2009). Credibility of electronic word-of-mouth: Informational and normative determinants of on-line consumer recommendations. International Journal of Electronic Commerce, 13(4), 9-38.

Chevalier, J. A., \& Mayzlin, D. (2006). The effect of word of mouth on sales: Online book reviews. Journal of Marketing Research, 43(3), 345-354.

Christensen, C. (1997). The Innovator's Dilemma: When New Technologies Cause Great Firms to Fail. Boston: Harvard Business School Press.

Connelly, B. L., Certo, S. T., Ireland, R. D., \& Reutzel, C. R. (2011). Signaling theory: A review and assessment. Journal of Management, 37(1), 39-67.

de la Peña, M. R., Núñez-Serrano, J. A., Turrión, J., \& Velázquez, F. J. (2016). Are innovations relevant for consumers in the hospitality industry? A hedonic approach for Cuban hotels. Tourism Management, 55, 184196.

De Vries, L., Gensler, S., \& Leeflang, P. S. (2012). Popularity of brand posts on brand fan pages: An investigation of the effects of social media marketing. Journal of Interactive Marketing, 26(2), 83-91.

Dellarocas, C., \& Wood, C. A. (2008). The sound of silence in online feedback: Estimating trading risks in the presence of reporting bias. Management Science, 54(3), 460-476.

Denrell, J., \& Le Mens, G. (2012). Following the crowd can lead people who learn only from their own experience to agree with a mistaken majority. Working Paper. [Retrieved from http://idei. fr/doc/conf/iast/paper_lemens. pdf.]

Edelman, B. G., \& Luca, M. (2014). Digital discrimination: The case of airbnb.com. Harvard Business School NOM Unit Working Paper, (14-054).

Ert, E., Fleischer, A., \& Magen, N. (2016). Trust and reputation in the sharing economy: The role of personal photos in Airbnb. Tourism Management, 55, 62-73.

Escobar-Rodríguez, T., \& Carvajal-Trujillo, E. (2013). An evaluation of Spanish hotel websites: Informational vs. relational strategies. International Journal of Hospitality Management, 33, 228-239.

Festinger, L. (1954). A theory of social comparison processes. Human relations, 7(2), 117-140. 
Fitzsimmons, J. A. (1985). Consumer participation and productivity in service operations. Interfaces, 15(3), 6067.

Forman, C., Ghose, A., \& Wiesenfeld, B. (2008). Examining the relationship between reviews and sales: The role of reviewer identity disclosure in electronic markets. Information Systems Research, 19(3), 291-313.

Fu, W. W., \& Sim, C. C. (2011). Aggregate bandwagon effect on online videos' viewership: Value uncertainty, popularity cues, and heuristics. Journal of the American Society for Information Science and Technology, 62(12), 2382-2395.

Fung, R., \& Lee, M. (1999). EC-trust: exploring the antecedent factors. In W. D. Haseman, \& D. L. Nazareth (Eds.), Proceedings of the Fifth Americas Conference on Information Systems (pp. 517e519). Milwaukee, WI.

Germann Molz, J. (2013). Social networking technologies and the moral economy of alternative tourism: The case of couchsurfing.org. Annals of Tourism Research, 43, 210-230.

Gunawan, D. D., \& Huarng, K. H. (2015). Viral effects of social network and media on consumers' purchase intention. Journal of Business Research, 68(11), 2237-2241.

Guttentag, D. (2015). Airbnb: disruptive innovation and the rise of an informal tourism accommodation sector. Current Issues in Tourism, 18(12), 1192-1217.

Guttentag, D.A., \& Smith, S.L. (2017). Assessing Airbnb as a disruptive innovation relative to hotels: Substitution and comparative performance expectations. International Journal of Hospitality Management, 64, 1-10.

Helm, R., \& Mark, A. (2007). Implications from cue utilization theory and signaling theory for firm reputation and the marketing of new products. International Journal of Product Development, 4(3), 396e411.

Heo, C. Y. (2016). Sharing economy and prospects in tourism research. Annals of Tourism Research, 58(C), 166-170.

Huang, J.H., \& Chen, Y.F. (2006). Herding in online product choice. Psychology \& Marketing, 23(5), 413-428.

Huang, P., Lurie, N. H., \& Mitra, S. (2009). Searching for experience on the web: an empirical examination of consumer behavior for search and experience goods. Journal of Marketing, 73(2), 55-69.

Humphreys, A., \& Grayson, K. (2008). The intersecting roles of consumer and producer: a critical perspective on co-production, co-creation and prosumption. Sociology Compass, 2(3), 963-980.

Huettner, F., \& Sunder, M. (2012). Axiomatic arguments for decomposing goodness of fit according to Shapley and Owen values. Electronic Journal of Statistics, 6, 1239-1250. doi:10.1214/12-ejs710

Ikkala, T., \& Lampinen, A. (2015, February). Monetizing network hospitality: Hospitality and sociability in the context of Airbnb. In Proceedings of the 18th ACM conference on computer supported cooperative work \& social computing (pp. 1033-1044). ACM.

ISI Web of Science, 2017: ISI Web of Science (accessed February, 5, 2017) [Retrieved from: https://www.webofknowledge.com/]

Jiang, Z., \& Benbasat, I. (2007). Research note-investigating the influence of the functional mechanisms of online product presentations. Information Systems Research, 18(4), 454-470.

John, N. A. (2013). The social logics of sharing. The Communication Review, 16(3), 113-131.

Johnson, A. G., \& Neuhofer, B. (2017). Airbnb-An exploration of value co-creation experiences in Jamaica. International Journal of Contemporary Hospitality Management, (forthcoming).

Ke, Q. (2017). Sharing Means Renting?: An Entire-Marketplace Analysis of Airbnb. In Proceedings of the 2017 ACM on Web Science Conference. 131-139. Available at SSRN: https://ssrn.com/abstract=2902840 or http://dx.doi.org/10.2139/ssrn.2902840.

Kennedy, J. (2016). Conceptual boundaries of sharing. Information, Communication \& Society, 19(4), 461-474.

Kim, J., \& Tussyadiah, I. P. (2013). Social networking and social support in tourism experience: The moderating role of online self-presentation strategies. Journal of Travel \& Tourism Marketing, 30(1-2), 7892.

Labrecque, L. I., Markos, E., \& Milne, G. R. (2011). Online personal branding: processes, challenges, and implications. Journal of Interactive Marketing, 25(1), 37-50.

Lee, B. K., \& Lee, W. N. (2004). The effect of information overload on consumer choice quality in an on-line environment. Psychology \& Marketing, 21(3), 159-183.

Lee, D., Hyun, W., Ryu, J., Lee, W. J., Rhee, W., \& Suh, B. (2015). An analysis of social features associated with room sales of Airbnb. In Proceedings of the 18th ACM Conference Companion on Computer Supported Cooperative Work \& Social Computing (pp. 219-222). ACM.

Li, J., Moreno, A., \& Zhang, D. J. (2015). Agent behavior in the sharing economy: Evidence from Airbnb. Ross School of Business Working Paper Series, (1298).

Liang, S., Schuckert, M., Law, R., \& Chen, C. C. (2017). Be a "Superhost": The importance of badge systems for peer-to-peer rental accommodations. Tourism Management, 60, 454-465.

Lipovetsky, S., \& Conklin, M. (2001). Analysis of regression in game theory approach. Applied Stochastic Models in Business and Industry, 17(4), 319-330. 
Liu, S.Q., \& Mattila, A. S. (2017). Airbnb: Online targeted advertising, sense of power, and consumer decisions. International Journal of Hospitality Management, 60, 33-41.

Liu, Y. (2006). Word of mouth for movies: Its dynamics and impact on box office revenue. Journal of Marketing, 70(3), 74-89.

Liu, Z., \& Park, S. (2015). What makes a useful online review? Implication for travel product websites. Tourism Management, 47, 140-151.

Lu, C., \& Kandampully, J. (2016). What drives customers to use access-based sharing options in the hospitality industry?. Research in Hospitality Management, 6(2), 119-126.

Mao, Z., \& Lyu, J. (2017). Why travelers use Airbnb again? An integrative approach to understanding travelers' repurchase intention. International Journal of Contemporary Hospitality Management, (forthcoming).

Mauri, A. G., \& Minazzi, R. (2013). Web reviews influence on expectations and purchasing intentions of hotel potential customers. International Journal of Hospitality Management, 34, 99-107.

Mody, M. A., Suess, C., \& Lehto, X. (2017). The accommodation experiencescape: a comparative assessment of hotels and Airbnb. International Journal of Contemporary Hospitality Management, (forthcoming).

Möhlmann, M. (2015). Collaborative consumption: Determinants of satisfaction and the likelihood of using a sharing economy option again. Journal of Consumer Behaviour. 14: 193-207.

Mudambi, S.M., \& Schuff. D. (2010). What makes a helpful online review? A study of consumer reviews on amazon.com. MIS Quarterly 34(1).185-200.

Oskam, J., \& Boswijk, A. (2016). Airbnb: the future of networked hospitality businesses. Journal of Tourism Futures, 2(1), 22-42.

Owen, G. (1977). Values of games with a priori unions. In Mathematical economics and game theory (pp. 7688). Springer Berlin Heidelberg.

Pappas, N. (2017). The complexity of purchasing intentions in peer-to-peer accommodation. International Journal of Contemporary Hospitality Management, 29(9), 2302-2321.

Park, D. H., Lee, J., \& Han, I. (2007). The effect of on-line consumer reviews on consumer purchasing intention: The moderating role of involvement. International Journal of Electronic Commerce, 11(4), 125148.

Park, S. S., Kim, Y. S., \& Kang, B. H. (2003). Web Information Management System: Personalization and Generalization. In ICWI (p. 532).

Pavlou, P. A., \& Dimoka, A. (2006). The nature and role of feedback text comments in online marketplaces: Implications for trust building, price premiums, and seller differentiation. Information Systems Research, 17(4), 392-414.

Pera, R., Viglia, G., \& Furlan, R. (2016). Who Am I? How Compelling Self-storytelling Builds Digital Personal Reputation. Journal of Interactive Marketing, 35, 44-55.

Peris-Ortiz, M., Fuster-Estruch, V., \& Devece-Carañana, C. (2014). Entrepreneurship and Innovation in a Context of Crisis. In Entrepreneurship, Innovation and Economic Crisis (pp. 1-10). Springer International Publishing.

Poon, K.Y., \& Huang, W.J. (2017). Past experience, traveler personality, and tripographics on intention to use AirBnB. International Journal of Contemporary Hospitality Management, (forthcoming).

Prahalad, C. K., \& Ramaswamy, V. (2004). Co-creation experiences: The next practice in value creation. Journal of Interactive Marketing, 18(3), 5-14.

PricewaterhouseCoopers (2015). The Sharing Economy. Consumer Intelligence Series. (Accessed February, 5, 2017) [Available at: http://www.pwc.com/us/en/industry/entertainment-media/publications/consumerintelligence-series/sharing-economy.html.]

PricewaterhouseCoopers (2016). Staying power. European cities hotel forecast for 2016 and 2017. (Accessed November, 16, 2017) [Available at: https://www.pwc.com/gx/en/hospitality-leisure/pdf/european-citieshotel-forecast-2016-2017.pdf.]

Priporas, C.V., Stylos, N., Rahimi, R., \& Vedanthachari, L. N. (2017). Unraveling the diverse nature of service quality in a sharing economy: a social exchange theory perspective of Airbnb accommodation. International Journal of Contemporary Hospitality Management 29(9), 2279-2301.

Resnick, P., \& Zeckhauser, R. (2002). Trust among strangers in Internet transactions: Empirical analysis of eBay's reputation system. In The Economics of the Internet and E-commerce (pp. 127-157). Emerald Group Publishing Limited.

Romenti S., Minazzi R., Murtarelli G. (2011). Online relationships and dialogue orientation in the Italian hospitality industry, Proceedings 14th Toulon-Verona Conference "Organizational Excellence in Services", University of Alicante - University of Oviedo (Spain), 1-3 September 2011.

Ronald, R. (2008). The ideology of home ownership: homeworker societies and the role of housing. New York: Macmillan.

Sabate, F., Berbegal-Mirabent, J., Cañabate, A., \& Lebherz, P. R. (2014). Factors influencing popularity of branded content in Facebook fan pages. European Management Journal, 32(6), 1001-1011. 
Salganik, Matthew J. and Duncan J. Watts (2008). Leading the herd astray: an experimental study of selffulfilling prophecies in an artificial cultural market. Social Psychology Quarterly, 71 (4), 338-55.

Schneider, H. (2017). Uber: Innovation in Society. Palgrave, Springer International Publishing AG, Cham, Switzerland.

Schor, J. B., \& Fitzmaurice, C. J. (2015). 26. Collaborating and connecting: the emergence of the sharing economy. Handbook of research on sustainable consumption, 410.

Shapley, L.S. (1953). Additive and Non-additive Set Functions. Princeton University.

Sigala, M. (2015). Gamification for crowdsourcing marketing practices: Applications and benefits in tourism. In Advances in crowdsourcing (pp. 129-145). Springer International Publishing.

Sigala, M. (2015). Collaborative commerce in tourism: implications for research and industry. Current Issues in Tourism, 20(4), 346-355.

Soriano, D. R., \& Huarng, K. H. (2013). Innovation and entrepreneurship in knowledge industries. Journal of Business Research, 66(10), 1964-1969.

Sparks, B. A., \& Browning, V. (2011). The impact of online reviews on hotel booking intentions and perception of trust. Tourism Management, 32(6), 1310-1323.

Spence, M. (2002). Signaling in retrospect and the informational structure of markets. American Economic Review, 92: 434-459.

Sundararajan, A. (2014). Peer-to-peer businesses and the sharing (collaborative) economy: Overview, economic effects and regulatory issues. Written testimony for the hearing titled The Power of Connection: Peer to Peer Businesses.

Teubner, T., Hawlitschek, F., \& Dann, D. (2017). Price Determinants On Airbnb: How Reputation Pays Off In The Sharing Economy. Journal of Self-Governance and Management Economics, 5(4), 53-80.

Toffler, A., \& Alvin, T. (1981). The third wave (pp. 32-33). New York: Bantam books.

Trefzger, T., Baccarella, C. and Voigt, K.I. (2015). Antecedents of brand post popularity in Facebook: The influence of images, videos, and text. In Proceedings of the 15th International Marketing Trends Conference (2016). Available at SSRN: https://ssrn.com/abstract=2697458

Tussyadiah, I. P. (2016a). Factors of satisfaction and intention to use peer-to-peer accommodation. International Journal of Hospitality Management, 55, 70-80.

Tussyadiah, I. P. (2016b). Strategic self-presentation in the sharing economy: Implications for host branding. In Information and Communication Technologies in Tourism 2016 (pp. 695-708). Springer International Publishing.

Tussyadiah, I. P., \& Pesonen, J. (2015). Impacts of peer-to-peer accommodation use on travel patterns. Journal of Travel Research, 55(8), 1022-1040.

Tussyadiah, I.P., \& Zach, F. (2017). Identifying salient attributes of peer-to-peer accommodation experience. Journal of Travel \& Tourism Marketing, 34(5), 636-652.

Varma, A., Jukic, N., Pestek, A., Shultz, C. J., \& Nestorov, S. (2016). Airbnb: Exciting innovation or passing fad?. Tourism Management Perspectives, 20, 228-237.

Viglia, G., Furlan, R., \& Ladron-de-Guevara, A. (2014). Please, talk about it! When hotel popularity boosts preferences. International Journal of Hospitality Management, 42, 155-164.

Viglia, G., Minazzi, R., \& Buhalis, D. (2016). The influence of e-word-of-mouth on hotel occupancy rate. International Journal of Contemporary Hospitality Management, 28(9), 2035-2051.

Viglia, G., \& Abrate, G. (2017). When distinction does not pay off-Investigating the determinants of European agritourism prices. Journal of Business Research, 80, 45-52.

Wang, D., \& Nicolau, J.L. (2017). Price determinants of sharing economy based accommodation rental: A study of listings from 33 cities on Airbnb.com. International Journal of Hospitality Management, 62, 120-131.

Wang, Q., Cui, X., Huang, L., \& Dai, Y. (2016). Seller reputation or product presentation? An empirical investigation from cue utilization perspective. International Journal of Information Management, 36(3), 271-283.

Williams, C.C. \& Horodnic, I.A. (2017). Regulating the sharing economy to prevent the growth of the informal sector in the hospitality industry. International Journal of Contemporary Hospitality Management, 29(9), 2261-2278.

Xie, H.J., Miao, L., Kuo, P.J., \& Lee, B.Y. (2011). Consumers' responses to ambivalent online hotel reviews: The role of perceived source credibility and pre-decisional disposition. International Journal of Hospitality Management, 30(1), 178-183.

Xie, K. L., \& Mao, Z. (2017). The impacts of quality and quantity attributes of Airbnb hosts on listing performance. International Journal of Contemporary Hospitality Management, (forthcoming).

Yacouel, N., \& Fleischer, A. (2012). The role of cybermediaries in reputation building and price premiums in the online hotel market. Journal of Travel Research, 51(2), 219-226.

Yannopoulou, N., Moufahim, M., \& Bian, X. (2013). User-generated brands and social media: Couchsurfing and AirBnb. Contemporary Management Research, 9(1), 85. 
Zervas, G., Proserpio, D. \& Byers, J. A First Look at Online Reputation on Airbnb, Where Every Stay is Above Average (January 28, 2015). Available at SSRN: https://ssrn.com/abstract $=2554500$

Zervas, G., Proserpio, D., \& Byers, J. W. (2015). The impact of the sharing economy on the hotel industry: evidence from Airbnb's entry into the Texas market. In Proceedings of the Sixteenth ACM Conference on Economics and Computation (pp. 637-637).

Zhu, G., So, K.K.F., \& Hudson, S. (2017). Inside the sharing economy: Understanding consumer motivations behind the adoption of mobile applications. International Journal of Contemporary Hospitality Management, 29(9), 2218-2239. 